\title{
PERCEIVED JUSTICE AT WORKPLACE AND ORGANIZATIONAL COMMITMENT*
}

\author{
Eralda Zhilla* \\ Arjana Muçaj ${ }^{* * *}$ \\ Blerina Hoti ${ }^{* * * *}$
}

Received: 13. 2. 2020

Preliminary communication

Accepted: 6. 8. 2020

UDC 005.32

DOI https://doi.org/10.30924/mjcmi.25.s.7

159.9-057.16

\begin{abstract}
The aim of this study is to investigate the relationship between the employees' perception of justice at the workplace, in relation to the organizational commitment. The study was carried out in Kosovo and its findings contribute to the service industry, being the most developed in that region. This especially applies to the banking sector, which is still in a transitional phase in Kosovo, with the potential benefit, in terms of better qualification of the staff. The data is collected from a sample of 256 participants, mainly from the
\end{abstract}

Abstract

banking sector $(N=148)$, but also other sectors, such as the public sector $(N=28)$, private business $(N=34), N G O s(N=26)$ and others $(N=20)$. This study hypothesizes that the perceived organizational justice has a positive effect on organizational commitment, with the empirical results supporting the hypothesis.

Keywords: perceived justice, organizational commitment, workplace, employees.

\section{INTRODUCTION}

The performance of a company significantly depends on the effort that employees put into their work, beyond the general tasks, required for their position. Responsible employees, who are also committed, courageous, and smart, are considered one the main factors for the success of an organization (Jafari \& Bidarian, 2012). Organizational behaviours of individuals,

e.g., their social behaviours, behaviours beyond the duty and responsibility, organizational commitment and spontaneous behaviours, are all essential to the general performance at work today (Goudarzv et al., 2011). What makes an individual or an employee exhibit such organizational traits in the work environment? Perceived justice at the workplace, which refers to an individual's perception of the fair treatment from

* This research was carried out within the Erasmus + Programme of the European Union in the framework of Strategic Partnership project "Cultural Studies in Business" (ERASMUS 2018-1-IT02-KA203-048091). The paper reflects only the views of the authors, and the European Commission cannot be held responsible for any use, which may be made of the information contained therein.

** Eralda Zhilla, PhD, Lecturer, University of Tirana, Faculty of Social Sciences, Bulevardi Gjergj Fishta, Tirana, Albania, Phone: +355 672530164, E-mail: adazhilla@gmail.com, ORCID: https://orcid.org/0000-0003-2061-6892

*** Arjana Muçaj, PhD, associate professor, University of Tirana, Faculty of Social Sciences, Bulevardi Gjergj Fishta, Tirana, Albania; University College Wisdom, Rr. Medar Shtylla, Tirana, Albania, Phone: +355 696078328, E-mail: arjanamucaj@yahoo.it, ORCID: https://orcid.org/0000-0001-9894-9123

**** Blerina Hoti, MSc, ProCredit Bank, Kosovo, Phone: :+38649612422, E-mail: blerinakuqi@gmail.com, ORCID: https://orcid.org/0000-0002-2979-6466 


\section{Journal of Contemporary Management Issues}

the company and the supervisors, is considered an important factor, which leads to the answer to the previous question (Chou et al., 2013). The way employees perceive how they are being treated within an organization, including their perception of the contribution to the company and the benefits received, play an important role in the performance at work and the commitment towards the duties and responsibilities, as well as the attitude towards the colleagues, supervisors and the company in general. Thus, on the one hand, the topic of this study is perceived justice at the workplace, while on the other hand, it is the organizational commitment, as one of the most important organizational behaviours. The organizational commitment is closely related to job satisfaction, which consists of an individual's relation, or attachment with an organization (Silverthorne, 2005). Their role is even higher, if combined, while it should be noted that organizational justice can predict organizational commitment (Suliman \& AlKathairi, 2013). Moreover, their role varies across national and cultural contexts (Jiang, Gollan \& Brooks, 2015). Therefore, studying them in a developing country, will serve as a direct contribution to the expansion of such concepts in the field of organizational psychology.

The study is conducted in Kosovo and its findings will contribute to the service industry, being the most developed in that region, contributing to more than half of the country's GDP and driving its economic development in the last decade (Cojocaru, 2017). Banking is the most significant part of the service industry, with ten commercial banks, and assets which amount to a value of EUR 3,186.8 million (Balija et al., 2015). The majority of this study has been conducted in the banking industry, which is transforming gradually from the traditional high-street banking to online banking
(Tornjanski et al., 2015), implying a change from standard and simple banking services to digitalised and more specialised ones. This means that the dynamics of the work of bank employees is undergoing changes, because of the use of technology, which is replacing routine tasks. It will give the employees more space, time and opportunity for deeper analysis and better professional qualification. As a result, the findings of the given study will help banks to achieve a better qualification of their staff.

In the following paragraphs, perceived justice at workplace and organizational commitment will be defined, their role within the organization and their relation will be described, and an overview of the existing literature and previous research will be provided.

\section{LITERATURE REVIEW}

\subsection{Definition of organizational justice}

Organizational justice is a concept, which has been discussed, by using such concepts as proper treatment and management. For example, Chegini (2009), interpreting Plato, considered it as a symbol of citizenship. The same author also interpreted the research of Abraham Maslow and commented that justice is an essential need, classified in the same group with rules and authenticity, as preconditions for fulfilment of human needs. The well-known philosopher Rawls called it a virtue of the organization and the society (quoted in Mohammad et al., 2010: 15).

Organizational justice, as developed by the Western scholars, such as Stacey Adams, Jerald Greenberg, Rusell Cropanzano, Jason A. Colquitt, Robert H. 
Moorman etc., is one of the social justice dimensions. In his Equity Theory, developed in 1963, Adams stated that individuals experience a kind of stress, when they perceive that they are not rewarded or that they are being rewarded differently than they deserve (Adams, 1965). This stress makes them react in a way, helping them bring justice into effect (Huseman et al., 1987; Hatfield \& Mi, 1987). Hence, in general, people are satisfied, when they receive a reward, in the amount that they consider fair in proportion to their contribution. If this is continuously applied in the workplace, then employees will be satisfied only, if their inputs and contributions at work are equal to the level of their outputs, or other rewards, such as salary, competencies, promotions, opportunities for professional development, and other benefits. This comparison goes even further when the employees compare their inputs and outputs with the other members of the same organization (Zeqiri, 2006), or when the result of each employee's input is equal to the results of other employees' inputs (Canco-Doraci, 2009). The employees' perceptions of justice, which is related to the treatment received at their workplace and their behavioural reaction, is a premise of organizational justice (Chou et al., 2013).

The term organizational justice, in general, refers to the individual perceptions of the workplace, which are related to both the individual and the company (Johnson et al., 2006). Moorman (1991:845) stated that this concept is concerned with the ways, in which employees determine if they have been treated fairly in all aspects. When injustice takes place at work, a destructive effect will be noticed in the process of development, because injustice obscures the efforts and motivation of the staff, demoralizes them and decreases their effectiveness and performance (Chegini, 2009).
The organizational justice is divided into four components: distributive, procedural, interactional or interpersonal and informational (Colquitt, 2001).

Distributive justice refers to the distribution of employee outcomes in the organization in any form, be it a reward, or a punishment. Its origin derives from the Adams's 'Equity Theory' model, which defines it as the equal distribution of outcomes over inputs (Adams, 1965: 272). Employees get paid for their work, therefore, their perception of their income, the salary level that they receive, and their consideration if this and other opportunities such as promotion or other rewards are deserved in the company, are all strongly related to distributive justice. It focuses on the ideal reward amount, which an employee deserves, related to the value of their contribution to the organization (Titrek et al., 2014).

Procedural justice, on the other hand, focuses on the employees' perceptions of the process, through which reward or remuneration is determined and allocated. According to Greenberg (as quoted in Zeinabadi and Salehi, 2011), procedural justice reflects an employees' judgements about the fairness of allocations decisions, related to their salaries (ibid, 2011: 1473). Employees react towards the decisions that affect them and processes that influence such decisions. Therefore, procedural justice requires that the procedures are approved and implemented fairly and with equal opportunities for everyone. Procedural justice refers to the perception of justice over procedures and decisions, through which income and other rewards are distributed (Asgari et al., 2011). According to Blader and Tyler (2003), individuals accept smaller rewards only, when they consider that the decision-making 


\section{Journal of Contemporary Management Issues}

process for their allocation has been just and fair.

The interactional justice was initially mentioned by Bies and Moag, who stated that "people are certainly concerned about the formal procedures used in a decisionmaking process, they are also concerned about interpersonal treatment that they receive from another person" (Bies, 2001: 91). While the procedural justice comprises the formal procedures and structures of the organization, the interactional justice focuses on the quality of treatment of the employees, when these procedures are implemented. According to Blakely et al. (2005), interactional justice reflects the employees` feelings on how fairly they are treated by their superiors.

The last dimension, informative justice, refers to the distribution of information to the employees in a fair and equal way, which is mainly related to the procedures, the clarity of objectives, work results, etc. It is related to the quantity, nature, focus and time of the information provided to an individual (Gilliland \& Paddock, 2005).

\subsection{Organizational commitment}

Similar to the notion of perceived organizational justice, organizational commitment, as a part of the human resource management, has also attracted the attention of both employers in different organizations and researchers, especially since the 1980s. Overall organizational commitment can be described as the level of employees' commitment towards an organization, which employs them and where they wish to continue working. Commitment refers to the employees' feelings and behaviours toward their company (Jex, 2002). According to Midday et al.'s definition, organizational commitment is "the relative strength of an individual's identification through the involvement in a particular organization," (quoted in Meyer and Allen, 1991: 64). Based on this concept, scholars have identified three components: (1) the desire to be a member of an organization; (2) the belief in and acceptance of the values and goals of the organization and (3) the will to make efforts in the name of the organization (Arnold, 2005). Following Myers and Allen's three-component model of commitment, organizational commitment consists of three different components:

1. Affective (organizational) commitment (the desire to stay), which refers to the individual's emotional attachment to the organization. According to Boselie (2010), this type of commitment is the most important one for employers, because it reflects the employees "level of identification with the organization, its values and goals as well as their sincere feelings of loyalty towards the company".

2. Continuance commitment (the need to stay) is the individual's perception of the costs and risks of leaving the organization. It reflects the connection with the organization, because of the lack of other opportunities or alternatives. It is based on the investments that they have made in the organization and the costs of leaving it and joining another company. Hence, it includes two kinds of variables: perceived investments and perceived alternatives (Rogelberg, 2007).

3. Normative commitment (moral obligation to stay), which is the individual's moral dimension of obligation and responsibility towards the organization (Meyer et al., 1993). Employees with a high organizational commitment are needed by the company, as they assist in making positive changes. In order to 
keep them in the company, the employers should invest in increasing their organizational commitment (Ahmed et al., 2011). It can also predict the turnover rate and staff replacement, with a higher level of organizational commitment leading to higher productivity and performance and lower levels of absenteeism (Brown et al., 2007).

The results of a study conducted within the IT departments in the Jordanian banking sector show that the commitment of the IT employees positively and significantly affected organizational performance and job satisfaction (Al-dalahmeh, et al., 2018). Another study, conducted in the branches of a Persian Bank in Tehran, Iran, show that organizational commitment and its components have a significant positive impact on market-orientation of Persian banks (Khoshnamnoghadam, 2017).

Scholars have conducted many studies on the relationship between the perception of organizational justice and organizational commitment, in order to understand their relationship. Mendryk (2017) conducted a study in Poland to determine the impact of procedural and distributive justice upon organization commitment of age-diversified employees. The results of the study show that, regardless of the respondents' age, the change in the perception of organizational justice will exert a positive impact upon organization commitment. Another study was conducted in three different authorized car dealers (Audi-Seat, Volkswagen and Skoda - four brands) of Doğuş Otomotiv in Konya, Turkey by Çağliyan et al. (2017). Their results indicate the existence of a statistically significant and positive relationship between participants' organizational justice perception and the levels of their organizational commitment.
The purpose of a meta-analysis, performed by Kamile (2016), was to investigate the relationship between teachers' organizational justice perceptions, organizational commitment and job satisfaction in schools. An extensive literature search was conducted to identify both published and unpublished reports that examined the relationship between teachers' perceptions of justice, job satisfaction and organizational commitment. In total, research reports provided usable data for 24 independent samples, in which teachers' overall perception of justice was positively related to organizational commitment.

A study conducted by Rahman et al. (2017), with data collected from a target population of lecturers of three public sector universities in the province of Khyber Pakhtun Khwa in Pakistan, measured the relationship among the distributive justice and procedural justice (as independent variables), with the organizational commitment as a dependent variable, by analysing the sample of 500 employees. Results of this study show that both distributive and procedural justice have significant and positive effects on employees' organizational commitment.

A study by Batool (2013) identified the relationships between organizational justice, on the one hand, and organizational commitment and citizenship behaviours on the other. The data in this study was collected from 17 different banks in the city of Peshawar in Pakistan, where a positive and significant relationship between organizational justice and organizational commitment was identified.

The causal relationship between organizational justice and organizational commitment was investigated by Iqbal \& Ahmad (2016) in several private commercial banks, operating in the Attock District Punjab, 


\section{Journal of Contemporary Management Issues}

Pakistan, who found a strong impact of organizational justice on the organizational commitment.

A study by Imamoglu et al. (2019) conducted in Kocaeli and Istanbul, Turkey, analyzed the relationships among organizational justice, organizational commitment, knowledge sharing, and company performance, finding that they are all affected by organizational justice.

Mohsan (2015) investigated the phenomenon of organizational justice with regard to organizational commitment in the banking sector of Pakistan and found a significant and positive association of organizational justice to employee commitment.

\section{METHODOLOGY}

\subsection{Purpose and hypothesis}

The purpose of this study is to investigate the relationship between the perceived organizational justice and organizational commitment. Referring to previous research, presented in the previous section of the paper and its results, the following research hypothesis has been formulated:

The perceived organizational justice has a positive effect on organizational commitment.

\subsection{Research participants}

Since the aim of the study is to measure the effect of organizational justice on employees' organizational commitment, in general, as well as by placing the special emphasis on the banking sector, the study participants were divided into two groups. The first group consisted of participants from the banking sector in Kosovo and the second one included those, working in other sectors. Data was collected from a total of 256 participants $(\mathrm{N}=256)$, out of which 148 were from the banking sector and 108 from other sectors. Out of them, $39 \%$ of the participants were male and $61 \%$ female. A total of $62 \%$ of participants were 26 to 35 years old, $23 \%$ were over 36 years old and $15 \%$ were under the age of 26. Other demographic information included the participants' marital status, their level of education and years of experience in the company, their position in the company, the number of employers they were working for until participating in this study.

\subsection{Instruments}

The measuring scales include the instruments for measuring the perceived justice at work and the organizational commitment (Boselie, 2010). The instrument for measuring perceived organizational justice was developed by Niehoff and Moorman and was first used in their studies in the 1990s (Moorman, 1991; Niehoff \& Moorman, 1993). The original version of this scale consists of a dimension that measures the perceptions of distributive justice with five items, two other dimensions that measure the perceptions of procedural justice with 15 statements, i.e. formal procedures (measured by six items) and interactional justice (nine items) (Niehoff \& Moorman, 1993). The instrument for measuring organizational commitment was developed by Meyer, Allen \& Smith (1991) and used by Ellemers et al. in 1998, which the measuring scale used in this study is mostly based on. The measurement scale consisted of four statements that were designed to measure the general organizational commitment. The respondents expressed how much they agreed with each statement on a five-point Likert scale, with values ranging from 1 (strongly disagree), to 5 (strongly agree). 


\section{EMPIRICAL RESULTS}

Reliability of measurement scales, mean, standard deviation, minimum and maximum values are presented in Table

Table 1. Reliability of measuring scales

\begin{tabular}{lccccccc}
\hline $\begin{array}{l}\text { Measuring } \\
\text { Scale }\end{array}$ & Subscales & No. of items & $\begin{array}{l}\text { Cronbach } \\
\text { Alpha }\end{array}$ & \multicolumn{1}{l}{ Mean } & SD & Min. & Max. \\
\hline OJ & 11 & 0.87 & 3.66 & 6.95 & 3.43 & 4.12 \\
& Distributive & 5 & 0.71 & 3.73 & 3.14 & 3.47 & 4.12 \\
& Procedural & 6 & 0.88 & 3.61 & 4.55 & 3.43. & 3.74 \\
OC & & 4 & 0.84 & 3.92 & 3.02 & 3.67 & 4.07 \\
\hline
\end{tabular}

In general, it can be concluded that, on a five-point Likert scale, the mean value of participants' perception of the applied justice in their organization is 3.66 and the mean of their organizational commitment is 4.01. This implies that research participants generally agree that there is justice in their workplace and that they are committed to their company.

Table 2. Correlations

\begin{tabular}{lcccc}
\hline & $\begin{array}{c}\text { Distributive } \\
\text { Justice }\end{array}$ & $\begin{array}{c}\text { Procedural } \\
\text { Justice }\end{array}$ & $\begin{array}{c}\text { Organizational } \\
\text { Justice }\end{array}$ & OC \\
\hline Distributive Justice & 1 & & & \\
Procedural Justice & $.621^{* *}$ & 1 & 1 & \\
Organizational Justice & $.858^{* *}$ & $.935^{* *}$ & $.460^{* *}$ & 1 \\
OC & $.350^{* *}$ & $.461^{* *}$ & .4 \\
\hline
\end{tabular}

Note: ${ }^{*} \mathrm{p}<.01,{ }^{* *} \mathrm{p}<.001$
ANOVA is used to analyse and compare the dependent variables (OJ and OC) with more than two categories in the demographic data to see if there is any significant
1. The results show that the value of Cronbach's Alpha is quite high, indicating a satisfactory level of construct validity.
Results of the linear correlation, measured by the Pearson coefficient, are presented in Table 2. They indicate a significant positive association between organizational justice perception and organizational commitment.

difference between two or more groups. No significant effect of gender on the abovementioned variables has been identified: $t$ $(253)=-.038 ; \mathrm{p}>0.05$ (see Table 3 ). 


\section{Journal of Contemporary Management Issues}

Table 3. Testing of the gender effect significance

\begin{tabular}{|c|c|c|c|c|c|c|}
\hline & & \multicolumn{2}{|c|}{$\begin{array}{c}\text { Levene's Test } \\
\text { for equality } \\
\text { of variances }\end{array}$} & \multicolumn{3}{|c|}{ t-test for equality of means } \\
\hline & & $\mathbf{F}$ & Sig. & $\mathbf{t}$ & df & $\begin{array}{c}\text { Sig. } \\
\text { (two-tailed) }\end{array}$ \\
\hline \multirow{2}{*}{$\begin{array}{l}\text { Organizational } \\
\text { Justice }\end{array}$} & Equal Supposed Variances & .004 & .951 & -.038 & 253 & .970 \\
\hline & $\begin{array}{l}\text { Unequal Supposed } \\
\text { Variances }\end{array}$ & & & -.038 & 212.495 & .970 \\
\hline \multirow[t]{2}{*}{$\mathrm{OC}$} & Equal Supposed Variances & .040 & .841 & .713 & 253 & .477 \\
\hline & $\begin{array}{l}\text { Unequal Supposed } \\
\text { Variances }\end{array}$ & & & .704 & 200.472 & .482 \\
\hline
\end{tabular}

Linear regression is used to test the research hypothesis that the perceived justice at workplace can have a positive effect on organizational commitment. Results of the regression analysis are presented by Table 4.

Table 4. Linear regression model

\begin{tabular}{|c|c|c|c|c|c|c|}
\hline & \multirow[b]{2}{*}{ Model } & \multicolumn{2}{|c|}{ Unstandardized coefficients } & \multirow{2}{*}{$\begin{array}{c}\text { Standardized } \\
\text { coefficients } \\
\text { Beta } \\
\end{array}$} & \multirow[b]{2}{*}{$\mathbf{t}$} & \multirow[b]{2}{*}{ Sig. } \\
\hline & & B & Std. Dev. & & & \\
\hline \multirow[t]{2}{*}{1} & (Constant) & 2.009 & .247 & & 8.147 & .000 \\
\hline & Organizational Justice & .546 & .066 & .460 & 8.241 & .000 \\
\hline
\end{tabular}

Table 4 shows that there is a significant linear regression equation model, estimating the organizational commitment. Based on the adjusted $\mathrm{R}^{2}$ value, organizational justice explains a significant proportion of variance in organizational commitment $\left(\mathrm{R}^{2}\right.$ $=.212, \mathrm{p}<.01)$. It can be concluded that the empirical results confirm the research hypothesis, i.e. the more justice is applied in the workplace, the more committed employees will be toward their organization.

\section{DISCUSSION}

The hypothesis that the perceived justice at the workplace has a positive influence on organizational commitment is supported by the empirical results, with a positive correlation of (with the Pearson coefficient value of .460 and a significance level of .000 , i.e. $\mathrm{p}<0.01$ ), while in some other studies no positive relationship between these two variables was found. A study by Ahmed et al. (2011) proved a positive correlation between the perceived justice and organizational commitment $(\mathrm{R}=.429$ and $\mathrm{p}<0.01)$. Many other studies (Moorman et al., 1993; Mendryk, 2017; Sahin, 2013; Çağliyan et al., 2017; Wang et al., 2014; Demir, 2016; Rahman et al., 2017; Batool, 2013; Hasan, 2002, etc.) have also identified a positive and significant relationship between OJ and OC. On the other hand, there have been some studies, e.g. a study by Zeinabadi and Salehi (2011), in which the direct effect between $\mathrm{OJ}$ and $\mathrm{OC}$ was found to be empirically insignificant ( $\mathrm{p}>0.05$ ).

However, our empirical results cannot be generalized for all companies, i.e. even 
if one applies justice at work, it does not mean that this will necessarily make employees emotionally related or committed to their organization. They consider justice at work a normal process in terms of a correct, fair and professional functioning of an organization and this will not necessarily make them feel closer, or more connected to the organization, neither emotionally nor morally. Therefore, based on the results of this study, it can be concluded that employees' perceptions of justice at work have the power to influence their decisions to express their commitment towards the company.

\section{CONCLUSION AND RECOMMENDATIONS}

The conclusion, which can also serve as a recommendation for employers and individuals at supervisory or managerial positions, is that a constant effort should be made, as to apply justice toward the employees. By rewarding employees appropriately and treating them in a way felt to be deserved, the employees will feel as being fairly compensated. In addition, if the employees are empowered to participate in the decision-making process, related to initiating or changing different procedures, rules and instructions, related to work processes, they will, consequently, be encouraged to contribute more and will be more committed. Additional recommendations for future research are as follows:

- The future studies should use a larger sample, if the research is to be conducted in several sectors simultaneously.

- The questionnaire should be administered to managers/supervisors, in order to include their opinions, as well.
- Some other methods of data collection should be used, such as interviews, etc. Each dimension should be measured separately, using instruments with subscales for categories of both organizational justice (distributive, procedural, interactional and informative) and commitment (affective, continuance and normative).

\section{References}

1. Adams, J. S. (1965). Inequity in Social Exchange. Advances in Experimental Social Psychology, 2, 267 - 299.

2. Ahmed, I., Ramzan, M., Mohammad, S. K., \&Islam, T. (2011). Relationship between Perceived Fairness in Performance Appraisal and OCB; Mediating Role of Organizational Commitment. International Journal of Academic Research, 3, 15-19

3. Al-dalahmeh, M., Masa'deh, R., Khalaf, R.K.A. \& Obeidat, B.Y. (2018). The effect of Employee Engagement on Organizational Performance Via the Mediating Role of Job Satisfaction: The case of IT Employees in Jordanian Banking Sector. Modern Applied Science, 12(6), $17-43$

4. Arnold, J. (2005). Work Psychology Understanding Human Behaviour in the Workplace. Edinburgh, England: Pearson Education Limited.

5. Asgari, M. H., Nojabaee, S. S., \& Arjmand, F. (2011). The Relationship between the Organizational Justice and Organizational Citizenship Behavior of the Employees. Middle-East Journal of Scientific Research 10 (2), 141 - 148.

6. Batool, S. (2013). Developing Organizational Commitment and Organizational Justice to Amplify Organizational Citizenship Behavior 


\section{Journal of Contemporary Management Issues}

in Banking Sector. Pakistan Journal of Commerce and Social Sciences, 7 (3), $646-655$.

7. Balija, P., Kosumi, K., \& Rugovaj, M. (2015). Struktura e Asetevetë Industrisë Bankare. Periodiku Bankar (Shoqata e Bankavetë Kosovës), 14, 1-12.

8. Bies, R. J. (2001). Interactional (In) Justice: The Sacred and the Profane. Advances in Organizational Justice, 89 $-118$.

9. Blader, S. L. \& Tyler, T. R. (2003). What constitutes fairness in work settings? A four-component model pf procedural justice. Human Resource Management Review, 13, 107 - 126.

10. Blakely, G., Andrews, M. C., \& Moorman, R. H. (2005). The Moderating Effects of Equity Sensitivity on the Relationship between Organizational Justice and Organizational Citizenship Behaviors. Journal of Business and Psychology, 20, 259.

11. Brown, A., Kirpal, S. \& Rauner, F. Eds. (2007). Identities at Work. Dordrecht, The Netherlands: Springer.

12. Boselie, P. (2010). Strategic Human Resource Management - A Balanced Approach. New York and London: McGraw-Hill Education

13. Canco-Doraci, G. (2009). Menaxhimi i Burimeve Njerëzore. Tiranë, Albania: Geer

14. Chegini, M.G. (2009). The Relationship between Organizational Justice and Organizational Citizenship Behavior. American Journal of Economics and Business Administration 1, 173 - 176.

15. Chou, T., Chou S. T., Jiang, J. J. \& Klein, G. (2013). The Organizational Citizenship Behavior of IS personnel: Does Organizational Justice matter?.
Information \& Management, 50, 105 -111 .

16. Cojocaru, A. (2017). Diagnoza e vendeve të punës në Kosovë. World Bank, Washington, DC.

17. Colquitt, J. A. (2001). On the Dimensionality of Organizational Justice: A Construct Validation of a Measure. Journal of Applied Psychology, 86 (3), 386 - 400.

18. Çağliyan, V., Attar, M. \& El Nour Derra, M. (2017). The relationship between Organizational Justice Perception and Organizational Commitment: A study on Dogus Otomotiv authorized dealers in Konya. The Journal of Faculty of Economics and Administrative Sciences, 22(2), 599-612.

19. Ellemers, N., De Gilder, D., \& Van den Heuvel, H. (1998). Career - Oriented versus Team-Oriented Commitment and Behavior at Work.Journal of Applied Psychology, 83 (5), 717 - 730.

20. Gilliland, S.W., \& Paddock, L. (2005). Organizational Justice across Human Resource Management Decisions. International Review of Industrial and Organizational Psychology, 20, 149-175.

21. Goudarzvandchegini, M., Gilaninia Sh. \&Abdesonboli, R. (2011). Organizational Justice and Organizational Citizenship Behaviour Case Study: Rasht Public Hospitals. International Journal of Business Administration, 2, 42-49.

22. Hasan, A. (2002). Organizational Justice as a Determinant of Organizational Commitment and Intention to Leave. Asian Academy if Management Journal, 7 (2), 55-66.

23. Huseman, R. C., Hatfield, J. D. \& Miles, E. W. (1987). A New 
perspective on Equity Theory: The Equity Sensitivity Construct. Academy of Management Review, 12 (2), 222 $-234$.

24. Imamoglu, S. Z., Ince, H., Turkcan, H. \& Atakay, B. (2019). The Effect of Organizational Justice and Organizational Commitment on Knowledge Sharing and Firm Performance. Procedia Computer Science, 158, $899-906$

25. Iqbal, Q. \& Ahmad, B. (2016). Organizational Justice, Trust and Organizational Commitment in Banking Sector of Pakistan. Journal of Applied Economics and Business, 4 (1), 26-43.

26. Jafari, P. \&Bidarian, Sh. (2012). The Relationship between Organizational Justice and Organizational Citizenship Behaviour. Procedia - Social and Behavioral Sciences, 47, 1815-1820.

27. Jex, S.M. (2002). Organizational Psychology - A Scientist-Practitioner Approach. New York, NY: John Wiley \& Sons, Inc.

28. Jiang, Zh., Gollan, P.J., \& Brooks, G. (2015). Relationships between organizational justice, organizational trust and organizational commitment: a cross-cultural study of China, South Korea and Australia. The International Journal of Human Resource Management, 28 (7), 973-1004-

29. Johnson, R. E., Selenta, C., \& Lord R. G. (2006). When Organizational Justice and the self-concept meet: Consequences for the organization and its members. Organizational Behavior and Human Decision Processes, 99, 175-201.

30. Kamile, D. (2016). Relations between teachers' organizational justice perceptions and organizational commitment and job satisfaction in the school: A meta-analysis. International Journal of Human Sciences, 13 (1), 1408-1417.

31. Khoshnamnoghadam, F. (2017). The Impact of Organizational Citizenship Behaviour (OCB) and Organizational Commitment on Market - Orientation of the Banks (Case Study: Parsian Bank Branches in Tehran). International Journal Business and Management, 12 (9), 173-185.

32. Mendryk, I. (2017). The Impact of Procedural and Distributive Justice upon Organization Commitment of Age-Diversified Employee. Annales Universitatis Mariae CurieSkłodowska, LI (3), 107-114..

33. Meyer, J. P., \& Allen, N.J. (1991). A Three - Component Conceptualization of Organizational Commitment. Human Resource Management Review, 1(1), $61-89$.

34. Meyer, J. P., Allen, N.J., \& Smith, C. A. (1993). Commitment to Organizations and Occupations: Extension and test of a three- component conceptualization. Journal of Applied Psychology, 78 (4), 538 -551.

35. Mohammad, J., Habib, F. Q. B., \& Alias, M. A. B. (2010). Organizational Justice and Organizational Citizenship Behavior in Higher Education Institution. Global Business and Management Research: An International Journal, 2, 13 - 32.

36. Mohsan, M.F. (2015). Organizational Justice and Employee Commitment: The Practice and Case of Banking Sector. LAP LAMBERT Academic Publishing.

37. Moorman, R.H. (1991). Relationship between Organizational Justice and Organizational Citizenship Behaviors: Do Fairness Perceptions Influence 


\section{Journal of Contemporary Management Issues}

Employee Citizenship?. Journal of Applied Psychology, 76, 845 - 855.

38. Niehoff, B. P., \& Moorman, R. H. (1993). Justice as a Mediator of the Relationship between Methods of Monitoring and Organizational Citizenship Behavior. Academy of Management Journal, 36 (3), 527-556.

39. Rahman, A., Shahzad, N., Mustafa, K., Fayaz-Khan, M., \& Qurashi, F. (2016). Effects of Organizational Justice on Organizational Commitment. International Journal of Economics and Financial Issues, 6 (S3) 188-196.

40. Rogelberg, S. G. (2007). Encyclopedia of Industrial and Organizational Psychology. Thousand Oaks, CA: SAGE Publications, Inc.

41. Sahin, S. (2013). Mediator Role of Organizational Justice in the Relationship between Learning Organization and Organizational Commitment. International Journal of Academic Research, 5 (6), 57-67.

42. Silverthorne, C. P. (2005). Organizational Psychology in Cross - Cultural Perspective. New York and London: New York University Press.

43. Suliman, A. \& AlKathairi, M. (2013). Organizational justice, commitment and performance in developing countries: The case of the UAE. Employee Relations, 35 (1), 98-115. https://doi. org/10.1108/01425451311279438
44. Titrek, O., Polatcan, M., Gunes, D. Z. \& Sezen, G. (2014). The relationship among emotional Intelligence (EQ), Organizational Justice (OJ), Organizational Citizenship Behaviour (OCB). International Journal of Academic Research, 6 (1), 213-220.

45. Tornjanski, V., Marinkovic, S., Savoiu, G. \& Cudanov, M. (2015). A need for research Focus Shift: Banking Industry in the Age of Digital Disruption. Econophysics, Sociophysics \& Other Multidisciplinary Sciences Journal, 5 (3), 11-15.

46. Wang, X., Ma, L., \& Zhang, M. (2014). Transformational Leadership and Agency Workers' Organizational Commitment: The Mediating Effect of Organizational Justice and Job Characteristics. Social Behavior and Personality, 42 (1), 25-36.

47. Zeinabadi, H. \& Salehi, K. (2011). Role of Procedural Justice, Trust, Job Satisfaction, and Organizational Commitment in Organizational Citizenship Behavior (OCB) of Teachers: Proposing a Modified Social Exchange Model. Procedia -Social and Behavioral Sciences, 29, 1472 -1481 .

48. Zeqiri, I. (2006). Menaxhmenti Koncepte, Praktika, Zhvillim Aftësish. Tetovo (Macedonia): Tringa Design. 


\title{
PERCIPIRANA PRAVEDNOST NA RADNOM MJESTU I ODANOST ORGANIZACIJI
}

\author{
Eralda Zhilla \\ Arjana Muçaj \\ Blerina Hoti \\ Sažetak
}

Cilj ovoga rada bio je istražiti odnos između pravednosti na radnom mjestu, kako je percipiraju zaposlenici, u odnosu prema odanosti organizaciji. Istraživanje je provedeno na Kosovu, a njegovi rezultati doprinose uslužnoj djelatnosti, kao najrazvijenoj u navedenoj regiji. Ovo se posebno odnosi na bankarski sektor, koje je na Kosovu još uvijek u fazi tranzicije, a može imati koristi od ovog istraživanja u smislu boljeg kvalificiranja djelatnika. Podaci su prikupljeni na uzorku od 256 sudionika, uglavnom iz bankarskog sektora $(N=148)$, ali i ostalih sektora kao što su javni sektor $(N=28)$, privatni sektor $(N$ =34), nevladine organizacije $(N=26)$ i drugi sektori $(N=20)$. Hipoteza istraživanja je da percepcija organizacijske pravednosti pozitivno utječe na odanost organizaciji, što je potvrđeno u empirijskom istraživanju.

Ključne riječi: percipirana pravednost, organizacijska predanost, radno mjesto, zaposlenici. 
